\title{
Paternal age is affected by genetic abnormalities, perinatal complications and mental health of the offspring (Review)
}

\author{
DOMINIKA JANECZKO, MAGDALENA HOŁOWCZUK, ANNA ORZEŁ, \\ BARBARA KLATKA and ANDRZEJ SEMCZUK
}

Second Department of Gynecology, Medical University of Lublin, PL-20954 Lublin, Poland

Received September 12, 2019; Accepted November 19, 2019

DOI: $10.3892 /$ br.2019.1266

\begin{abstract}
Infertility and fecundity problems concern 10-18\% of partners in their reproductive years compromising around one million females and males in Poland. Research and analysis of factors that affect male fertility are limited, especially, regarding the age of the father and determining the age at which quality of semen decreases. Age of the father has greater impact than maternal age, on cases of sporadic autosomal dominant congenital diseases such as Apert, Crouzon, Pfeiffer, Noonan and Costello syndromes, multiple endocrine neoplasia (types 2A and 2B) and achondroplasia. However, there are only a few reports taking paternal advanced age into consideration for pre-mature birth, low Apgar scores or admission to a neonatal intensive care department. Paternal age increases the frequency of congenital diseases such as heart malformations as well as oral, palate and lip cleft. Moreover, mental disorders (autism, schizophrenia, bipolar disorder, low IQ level as well as ADHD) also occur more frequently in advanced father's age. Advanced paternal age is defined differently in every research. It depends on disorders in offspring we are talking about. Paternal age has an impact on child's health and development and it is as significant as maternal age, when it comes to reproductive matters.
\end{abstract}

\section{Contents}

1. Introduction

2. Genetic syndromes

3. Perinatal complications

4. Congenital defects

5. Mental disorders and children's neurocognitive abilities

6. Conclusions

Correspondence to: Dr Dominika Janeczko, Second Department of Gynecology, Medical University of Lublin, 8 Jaczewskiego, PL-20954 Lublin, Poland

E-mail: dominika.janeczko@gmail.com

Key words: paternal age, congenital abnormalities, autism, infertility, male, mental disorders

\section{Introduction}

Infertility and fecundity problems concern $10-18 \%$ of partners in their reproductive years comprising around one million females and males in Poland (1). According to the World Health Organization definition, infertility is a disease of the reproductive system defined by the failure to achieve a clinical pregnancy after 12 months or more of regular unprotected sexual intercourse (2). There are multiple factors affecting fertility in both sexes. Female causes include defects in ovulation, as well as transplantation and implantation of the ovum. Male causes involve abnormalities in spermatogenesis and delivery of the sperm (3). Moreover, epidemiological factors and change in the general pattern of living have a significant impact on fecundity problems. One of them is postponed decision about pregnancy.

As reported by The Demographic Yearbook of Poland 2017, in 2016, Poland recorded 382,257 live births (4). The Polish population was divided into groups according to age and sex in order to indicate differentiation in the fertility model. The highest rate of living births among women was observed within the group aged 25-29 years $(126,651)$, whereas in the case of men this value applies to the group aged 30-34 years $(135,909)$ (Fig. 1). Within the period 1980-2000, the statistics were different. The highest number of living births was observed in a group of women aged 20-24 years: 293,944 births in 1980; 199,575 in 1990 and 127,319 in 2000. In 2010, the pattern changed and the highest number of living births was evident in females aged 25-29 years (152,711). Data regarding fathers were not recorded in the statistics. It underlines the fact that the impact of paternal age regarding the offspring was neglected. While taking into account the fertility rate, it also revealed a decreasing tendency from 17.0 per 1,000 women (2000) to 12.3 per 1,000 (2015). Only female fertility was assessed (4).

The problem of infertility is shared equally (50\%) by both sexes (5). Research and analysis of factors that affect male fertility are limited, especially, regarding the age of the father (6). Data show that, with advanced age the quality of semen decreases resulting in 3-22\% decrease in semen volume, $3-37 \%$ in motility and $4-18 \%$ in normal morphology (7). These modifications follow anatomical and functional changes of the aging organism. Reduced volume of semen is a consequence of insufficiency of seminal vesicles and decreased 
motility follows smooth muscular atrophy in prostate (7). Moskovtsev et al (8) indicated the genetic implications followed by advanced parental age. That study presented decreased DNA integrity in a group of men above 45 years of age. In addition, males with higher DNA fragmentations have lowered chances in both in vitro and in vivo fertilization and further development of the embryo (8). Additionally, parental age has a significant impact on gene mutation. One example is single gene mutation of fibroblast growth factor receptor 3 (FGFR3), the cause of achondroplasia, commonly known as dwarfism. Similarly, advanced age of the father may increase the risk of FGFR2 mutations resulting in Crouzon, Apert, and Pfeiffer syndromes. Genetic mutations linked with advanced paternal age are associated with the stimulation of carcinogenesis especially in terms of breast cancer, childhood leukemia and childhood central nervous system tumors (9). Despite the fact that Down syndrome is commonly known as related to advanced maternal age, previous findings indicate that increased paternal age influences the chance of mutational development as well (9).

Apart from enhanced occurrence of somatic disorders, the effect of father's age on mental health and neurodevelopmental disorders in offspring is continuously being examined. A significant aspect is the correlation of autism and age of the parent. Previous findings suggest that the development of this disorder may result from epigenetic differences in paternal sperm. These changes may directly affect the cerebellum of the offspring (10). Moreover, advanced paternal age is an important factor with psychiatric conditions such as schizophrenia, bipolar disorder and even intelligence of the child (11). It also has an impact on future learning potential.

Currently, researchers have focused on determining a threshold level of the age of the father that is followed by negative implications on the developing fetus. Literature shows differentiated statistics ranging from 30 to 50 years of age, indicating the age of 40 as the threshold of advanced paternal age most frequently (9). Nevertheless, findings indicate the importance of the young age of the father in order that possible somatic and mental complications of the future offspring may be prevented.

\section{Genetic syndromes}

Paternal age has a greater impact on cases of sporadic autosomal dominant congenital diseases than maternal age, such as Apert, Crouzon, Pfeiffer, Noonan and Costello syndromes, multiple endocrine neoplasia (types $2 \mathrm{~A}$ and $2 \mathrm{~B}$ ) and achondroplasia (12) (Table I). The main cause is the difference in gametogenesis between men and women. Female oocytes do not go through DNA replication in the mature age in contrast to male spermatogenesis. Ageing leads to more DNA replications during spermatogenesis in testicles. It increases the risk of copy error mutations such as small deletions and insertions (13).

It is estimated that spermatic chromosomes are replicated 35 times by age 15,150 times by age 20,380 times by age 30 , 610 times by age 40 , and 840 times by age $50(14,15)$. In opposition to men, female gametogenesis can lead to aneuploidy, and it is also related to ageing (16). Moreover, men over the age of 45 are more likely to have a child with trisomy 21 , versus men less than 30 years of age (17). The examples of autosomal dominant diseases are Apert syndrome and achondroplasia, caused by mutations in fibroblast growth factor receptor 2 and 3 (FGFR2, FGFR3). Multiple endocrine neoplasia syndrome, is caused by mutations in $R E T$ gene, and it presents with tumors in two or more glands of the endocrine system (9).

\section{Perinatal complications}

There are only a few reports taking into consideration advanced paternal age as a reason for pre-mature birth, low Apgar score or admission to a neonatal intensive care department. This topic requires further investigation. There is no doubt that, older fathers are more likely to have infant with birth defects, stillbirth and low birthweight (18-22). An Italian study, conducted during the period 1990-1998 revealed that men aged 45 to 49 years had a higher risk of having a pre-term birth, than men aged 25 to 29 years (23). In the United States, a population-based cohort study between 2007 and 2016 reported that children born to fathers over the age of 45 had $14 \%$ higher risk of preterm birth (21). Additionally, for fathers aged over 35 years there was a higher risk of having a baby with low birthweight. Mothers with older partners had a 34\% higher risk of gestational diabetes. Furthermore, fathers over the age of 55, had a higher risk of having an infant with low (below 8) Apgar score (21).

\section{Congenital defects}

The most common congenital defects are heart malformations, which affect 5-10/1000 live births (24-26). Nevertheless there are divergences between studies, some of which confirm the connection of advanced paternal age with heart defects in offspring (27-30), while others are contradictory and show that older fathers have fewer heart defects in their children (31-33). One study reported that men over the age of 40 years were more likely to have a child with ventricular septal defect (VSD) but not atrial septal defect (ASD) (34). Moreover, surveys prove the increased risk of having patent ductus arteriosus (PDA) in the offspring of fathers older than 45 years $(28,35)$.

Oral cleft occurs in approximately 1-2/1000 live births. The probability of this defect increases with both paternal and maternal advanced age. In addition, the risk of an infant having a cleft lip decreases the younger both of the parents are. On the contrary, the risk of having a baby with a cleft palate is only connected with paternal advanced age $(36,37)$. The probability of having a child with cataract, esophageal atresia, diaphragmatic hernia, encephalocele or coarctation of the aorta increases with advanced paternal age. Babies born with omphalocele, spina bifida, orafacial clefts and septal heart defects were more common among older men with younger partners (38).

\section{Mental disorders and children's neurocognitive abilities}

A significant amount of attention has been devoted to the influence of the father's age on the child's mental development, the occurrence of mental disorders, cognitive and developmental abilities, intelligence, and even learning outcomes. Many 
Table I. Genetic disorders connected with advanced paternal age.

\begin{tabular}{|c|c|c|}
\hline Name of the disorder & Mutated gene & Phenotype \\
\hline Apert syndrome & FGFR2 & $\begin{array}{l}\text { Craniosynostosis, syndactyly, high-arched palate, mandibular prognathism, } \\
\text { crowded teeth }\end{array}$ \\
\hline Crouzon syndrome & FGFR2 & $\begin{array}{l}\text { Craniosynostosis, exophthalmos, hypertelorism, hypoplastic maxilla, } \\
\text { hypodontia }\end{array}$ \\
\hline Pfeiffer syndrome & FGFR2 & $\begin{array}{l}\text { Craniosynostosis, turribrachycephaly, proptosis, hypertelorism, maxillary } \\
\text { hypoplasia, syndactyly }\end{array}$ \\
\hline Noonan syndrome & PTPN11 & $\begin{array}{l}\text { Short height, congenital heart disease, hypertelorism, skeletal malformations, } \\
\text { bleeding problems }\end{array}$ \\
\hline Costello syndrome & $H R A S$ & $\begin{array}{l}\text { Intellectual disability, cardiac abnormalities, loose folds of skin on hands } \\
\text { and legs, too loose joints }\end{array}$ \\
\hline Achondroplasia & FGFR3 & Shortened arms and legs, prominent forehead, large head, trident hands \\
\hline
\end{tabular}

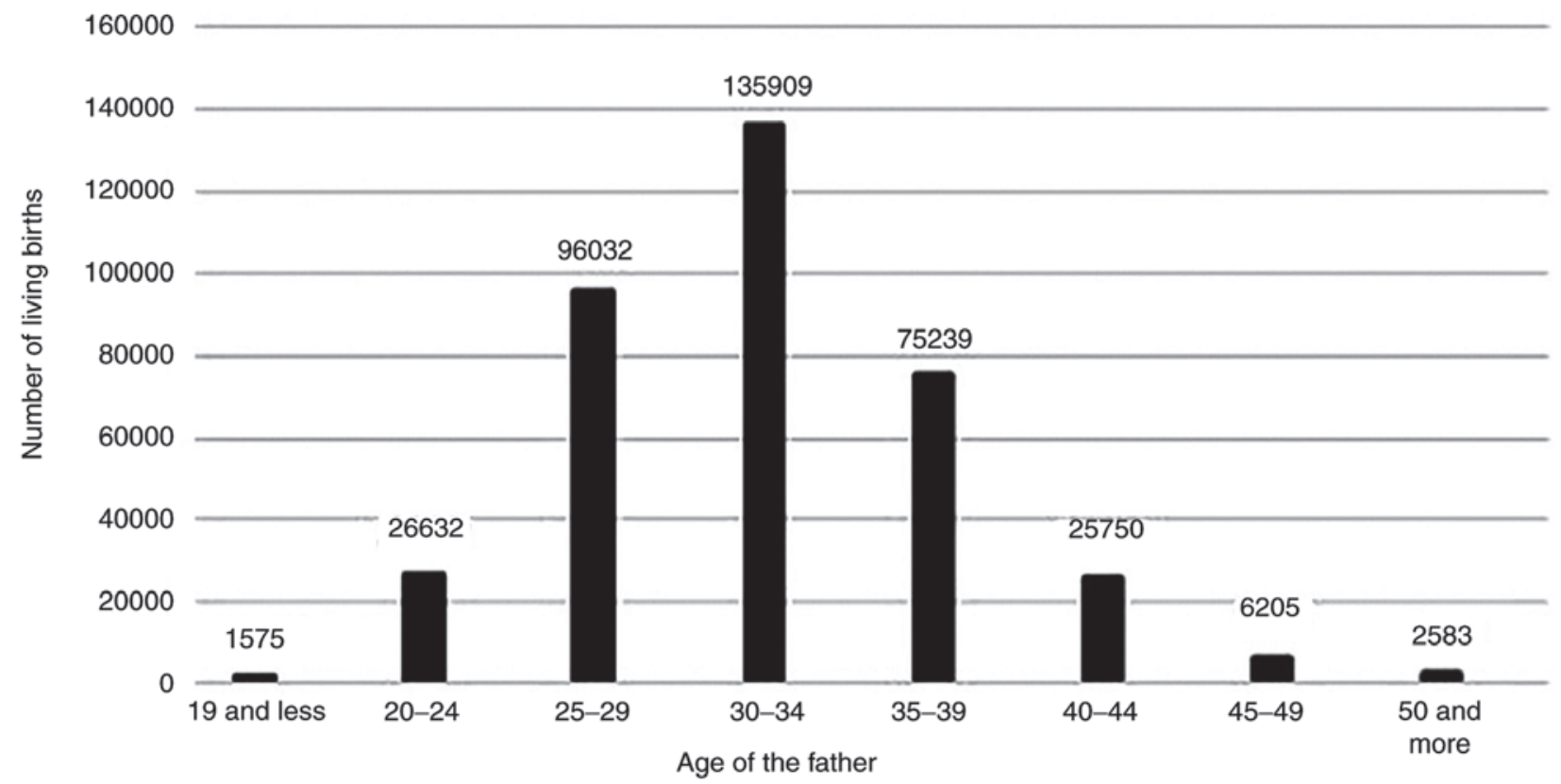

Figure 1. Graph showing number of live births by age of the father according to the data from 2016 in Poland (4).

studies linked advanced age of the father with behavioral and psychiatric conditions, whereas only a few studies are associated with developmental psychology $(11,39)$. The connection is particularly strong in autistic diseases and schizophrenia, while in the other cases a correlation is not well established.

Autism belongs to neurodevelopmental disorders. Social deficiencies, language difficulties, stereotypical behavior and early beginning of symptoms are the typical signs of the disease. Advancing paternal age is a significant risk factor for autism in offspring, which has been shown in many studies in recent years. Reichenberg and co-investigators found that in a cohort of nearly 400,000 individuals of paternal age above 40 years significantly increases the risk of having a child with autism (39). Additionally, the father's age can also affect subsequent generations. The levels of risk were similar for maternal and paternal grandfathers. The grand-paternal age risk estimates were lower than the risk estimates for paternal age, which is true to the hypothesis that the strength of a genetically mediated effect should reflect the genetic relatedness. The results of one of the most recent meta-analysis report a 2-fold higher probability of autism in the offspring of a father aged 50 than a father at the age of 30 (40). Moreover, the risk of autism increased with advancing grand-paternal age, which may be independent of the age of the mother and father. It is also observed that men above 50 years who have daughters are more likely to have grandchildren with autism (41). Associations between advanced paternal age and other mental disorders (schizophrenia, bipolar disorder, and general neurocognitive development) have also been observed (42-45). Furthermore, the relationship between a higher incidence of the disease and the childbirth sequence was also demonstrated. The risk of developing autism was the most significant for firstborn children (46). Paternal age effect was also connected with a higher risk of autism spectrum disorder with intellectual disability (47). 
The connection between paternal age and occurrence of autism has been well established by many studies. However, the exact mechanism has yet to be identified. Sebat et al (48) reported a severe connection of de novo copy number variations (CNVs) with autism in cases of sporadic autism. CNVs are the changes in the number of particular places of DNA that allows cells to contain deletions or duplications of given regions. Authors of that study showed that de novo mutations potentially result in both gain or loss of DNA region copy number, which can partially explain autism spectrum disorders $(48,49)$.

Different mutations associated with advanced age and epigenetic alterations are also considered to be the main reason for this phenomenon; however, the specific mechanisms remain to be determined. The basis for these changes may be the de novo mutations arising in male germ cells (50). The quality of semen decreases with age and the number of changes in the genetic materials increases. It is observed that levels of repair enzymes are lower and DNA fragmentations increase $(51,52)$. De novo mutations in autism have mainly paternal descent, as indicated in recent studies (53-56).

The advanced age of the father also contributes to schizophrenia and the spectrum of schizophrenia disorders. Researchers from the United States conducted a study involving 12,000 patients in which they showed an increased risk of having a child with autism with every 10 -year increase in the father's age (57). Research carried out on a group of 750,000 individuals in Sweden has published similar results (44). Moreover, the connection between paternal age and schizophrenia was evident only in cases with no family history, which may suggest that collection of de novo mutations in the sperm may increase the risk (58).

The influence of paternal age on schizophrenia and autism has been investigated for decades. It was debated whether it is also important in the development of psychotic-like symptoms in adult offspring that appear more frequently in the society. Data collected by researchers show the connection between advanced paternal age and the development of psychotic-like symptoms. Children with fathers above 35 years of age had 2.1-fold higher odds of psychotic-like symptoms. Interestingly, maternal age had no impact (45).

Another disease related to the father's age is bipolar disorder. It is a disease characterized by alternating periods of depression and manic mood. Recent findings have shown that, children of men above 55 years of age are almost 1.5 -fold more often diagnosed with bipolar disorder than offspring of fathers less than 25 years of age. Interestingly, the mother's age had no impact on the development of this disease (59).

Paternal age effect on other mental disorders was also studied. Interestingly, in the case of ADHD (attention-deficit hyperactivity disorder) an inverse relationship was observed. As the age of father decreases, the risk of having a child with ADHD increases. This connection was observed in a comprehensive, population-based record linkage study; however, scientists did not manage to identify a specific reason (60).

A few studies also examined the influence of the father's age on behavior and cognitive ability. Using neurocognitive measures such as the Wechsler Intelligence Scale for Children researchers have shown that children of older fathers had lower results (61). Another study showed the association of an advanced father's age with the occurrence of negative behaviors in children such as aggression, vandalism, and disruptive behavior. It was elucidated that for every 5-year increase in the father's age, the likelihood of higher defective demeanor increased by $12 \%(62,63)$. It was also indicated that offspring of fathers aged 45 years and older gained lower grades in science (64).

Association between the father's age and intelligence of the descendants was also studied. Due to many possible confounders such as socio-economic status, the level of parents' education, and parents' intelligence indicators, it may be complicated to analyze the link between paternal age effect and intelligence of offspring. However, there are many premises that should not be omitted. Investigators revealed a non-linear relationship with male children's verbal intelligence quotient (IQ) scores, despite considering possible disruptive factors (65). Moreover, it has been determined that children of older fathers have increased risk of obtaining a lower level of education and worse scores (66). Notably, research on a group of adolescents born to fathers younger than 20 years and older than 50 years of age, revealed that these groups achieved the lowest results in measures of non-verbal IQ (66).

There are also some signs that paternal age at birth appears to have an impact on psychosocial development in offspring. Children of younger and older men seem to have lower social skills and an increased risk of developing major depressive disorder $(65,66)$.

\section{Conclusions}

Paternal age appears to have a significant impact on a child's health and development. The quality of semen decreases with aging, resulting in DNA copy mutations. Similarly, a decrease in the volume of semen, can lead to problems with conception. It can therefore be said that the male biological clock is ticking, too. Available studies clearly link advanced paternal age at the age of conception with increased frequency of mental health disorders, such as bipolar disease, schizophrenia, autism or even a lower IQ level of the offspring. Advanced paternal age also has serious implications on genetic disorders, perinatal complications, congenital defects, or even carcinogenesis. Currently, much more data are available on the effects of maternal age on fetus. To summarize, more research is needed regarding the impact of paternal age on the developing fetus, health of mothers during pregnancy, growing child and complications in their adult age. However, at this point, we can certainly conclude, that paternal age is as significant as maternal age, when it comes to reproductive matters.

\section{Acknowledgements}

The authors would like to thank Barbara Zielinski Roman and Stacie Rhoades (Department of Epidemiology, Nationwide Children's Hospital, Columbus, OH, USA), and Filip Kacki $\mathrm{MD}$, for their support with linguistic correctness.

\section{Funding}

This study was supported by a grant from the Medical University of Lublin (Lublin, Poland) to AS (Dz. St. 326/19). 


\section{Availability of data and materials}

All the data and materials used and analyzed in this review are available from the corresponding Author on reasonable request.

\section{Authors' contributions}

DJ conceived and designed the review. $\mathrm{DJ}, \mathrm{AO}, \mathrm{MH}, \mathrm{BK}$ found literature and analyzed it. DJ, $\mathrm{AO}, \mathrm{MH}, \mathrm{BK}$ drafted the manuscript. AS critically revised and corrected the manuscript. All authors have read and approved the final version of the manuscript.

\section{Ethics approval and consent to participate}

Not applicable.

\section{Patient consent for publication}

Not applicable.

\section{Competing interests}

The authors declare they have no competing interests.

\section{References}

1. Łepecka-Klusek C, Pilewska-Kozak AB and Jakiel G: Niepłodność w świetle definicji choroby podanej przez WHO Med Og Nauk o Zdro 18: 163-166, 2012 (In Polish).

2. World Health Organization: Sexual and reproductive health https://www.who.int/reproductivehealth/topics/infertility/definitions/en/. Accessed June 4, 2019.

3. Anwar S and Anwar A: Infertility: A review on causes, treatment and management. Womens Health Gynecol 2: 1-5, 2016.

4. Demographic Yearbook of Poland 2017. Central Statistical Office pp266-272,2017.https://stat.gov.pl/en/topics/statistical-yearbooks/ statistical-yearbooks/demographic-yearbook-of-poland-2017,3,11. html. Accessed October 13, 2017.

5. Szkodziak P, Wozniak P, Czuczwar P, Woźniakowska E, Milart P, Mroczkowski A and Paszkowski T: Infertility in the light of new scientific reports-focus on male factor. Ann Agric Environ Med 23: 227-230, 2016.

6. Agarwal A, Mulgund A, Hamada A and Chyatte MR: A unique view on male infertility around the globe. Reprod Biol Endocrinol 13: 37, 2015.

7. Rogel R, Luján S, Broseta E, Age P and Concerns F: Paternal age and fertility concerns. Encyclopedia Repr 4: 301-306, 2018.

8. Moskovtsev SI, Willis J and Mullen JB: Age-related decline in sperm deoxyribonucleic acid integrity in patients evaluated for male infertility. Fertil Steril 85: 496-499, 2006.

9. Ramasamy R, Chiba K, Butler P and Lamb DJ: Male biological clock: A critical analysis of advanced paternal age. Fertil Steril 103: 1402-1406, 2015.

10. Feinberg JI, Bakulski KM, Jaffe AE, Tryggvadottir R, Brown SC, Goldman LR, Croen LA, Hertz-Picciotto I, Newschaffer CJ, Fallin MD and Feinberg AP: Paternal sperm DNA methylation associated with early signs of autism risk in an autism-enriched cohort. Int J Epidemiol 44: 1199-1210, 2015.

11. Malaspina D, Gilman C and Kranz TM: Paternal age and mental health of offspring. Fertil Steril 103: 1392-1396, 2015.

12. Goriely A and Wilkie AO: Paternal age effect mutations and selfish spermatogonial selection: Causes and consequences for human disease. Am J Hum Genet 10: 175-200, 2012.

13. Conti SL and Eisenberg ML: Paternal aging and increased risk of congenital disease, psychiatric disorders, and cancer. Asian J Androl 18: 420-424, 2016.

14. Speicher M, Antonarakis SE and Motulsky AG (eds): Vogel and Motulsky's Human Genetics: Problems and Approaches. 4th edition. Springer, 2010
15. Kong A, Frigge ML, Masson G, Besenbacher S, Sulem P, Magnusson G, Gudjonsson SA, Sigurdsson A, Jonasdottir A, Jonasdottir A, et al: Rate of de novo mutations, father's age, and disease risk. Nature 488: 471-475, 2012.

16. Kurahashi H, Tsutsumi M, Nishiyama S, Kogo H, Inagaki H and Ohye T: Molecular basis of maternal age-related increase in oocyte aneuploidy. Congenit Anom (Kyoto) 52: 8-15, 2012.

17. Zhu JL, Madsen KM, Vestergaard M, Olesen AV, Basso O and Olsen J: Paternal age and congenital malformations. Hum Reprod 20: 3173-3177, 2005.

18. Meng Y and Groth SW: Fathers count: The impact of paternal risk factors on birth outcomes. Matern Child Health J 22: 401-408, 2018.

19. Nybo Andersen AM, Hansen KD, Andersen PK and Davey Smith G: Advanced paternal age and risk of fetal death: A cohort study. Am J Epidemiol 160: 1214-1222, 2004.

20. Urhoj SK, Andersen PK, Mortensen LH, Davey Smith G and Nybo Andersen AM: Advanced paternal age and stillbirth rate: A nationwide register-based cohort study of 944,031 pregnancies in Denmark. Eur J Epidemiol 32: 227-234, 2017.

21. Alio AP, Salihu HM, McIntosh C, August EM, Weldeselasse H, Sanchez E and Mbah AK: The effect of paternal age on fetal birth outcomes. Am J Mens Health 6: 427-435, 2012.

22. Khandwala YS, Baker VL, Shaw GM, Stevenson DK, Lu Y and Eisenberg ML: Association of paternal age with perinatal outcomes between 2007 and 2016 in the United States: Population based cohort study. BMJ 363: k4372, 2018.

23. Yang Q, Wen SW, Leader A, Chen XK, Lipson J and Walker M: Paternal age and birth defects: How strong is the association? Hum Reprod 22: 696-701, 2007.

24. Astolfi P, De Pasquale A and Zonta LA: Paternal age and preterm birth in Italy, 1990 to 1998. Epidemiology 17: 218-221, 2006.

25. Bjornard K, Riehle-Colarusso T, Gilboa SM and Correa A: Patterns in the prevalence of congenital heart defects, metropolitan Atlanta, 1978 to 2005. Birth Defects Res A Clin Mol Teratol 97: 87-94, 2013.

26. Oyen N,Poulsen G, Boyd HA, Wohlfahrt J,Jensen PK and Melbye M: National time trends in congenital heart defects, Denmark, 1977-2005. Am Heart J 157: 467.el-473.e1, 2009.

27. Reller MD, Strickland MJ, Riehle-Colarusso T, Mahle WT and Correa A: Prevalence of congenital heart defects in metropolitan Atlanta, 1998-2005. J Pediatr 153: 807-813, 2008.

28. Materna-Kiryluk A, Wiśniewska K, Badura-Stronka M, Mejnartowicz J, Wieckowska B, Balcar-Boroń A, Czerwionka-Szaflarska M, Gajewska E, Godula-Stuglik U, Krawczyński M, et al: Parental age as a risk factor for isolated congenital malformations in a Polish population. Paediatr Perinat Epidemiol 23: 29-40, 2009.

29. Olshan AF, Schnitzer PG and Baird PA: Paternal age and the risk of congenital heart defects. Teratology 50: 80-84, 1994.

30. Baltaxe E and Zarante I: Prevalence of congenital heart disease in 44,985 newborns in Colombia. Arch Cardiol Mex 76: 263-268, 2006 (In Spanish).

31. Cedergren MI, Selbing AJ and Källén BA: Risk factors for cardiovascular malformation-a study based on prospectively collected data. Scand J Work Environ Health 28: 12-17, 2002.

32. Zhan SY, Lian ZH, Zheng DZ and Gao L: Effect of fathers' age and birth order on occurrence of congenital heart disease. J Epidemiol Community Health 45: 299-301, 1991.

33. Ewing CK, Loffredo CA and Beaty TH: Paternal risk factors for isolated membranous ventricular septal defects. Am J Med Genet 71: 42-46, 1997

34. Bassili A, Mokhtar SA, Dabous NI, Zaher SR, Mokhtar MM and Zaki A: Risk factors for congenital heart diseases in Alexandria, Egypt. Eur J Epidemiol 16: 805-814, 2000.

35. Su XJ, Yuan W, Huang GY, Olsen J and Li J: Paternal age and offspring congenital heart defects: A national cohort study. PLoS One 10: e0121030, 2015.

36. Bille C, Skytthe A, Vach W, Knudsen LB, Andersen AM, Murray JC and Christensen K: Parent's age and the risk of oral clefts. Epidemiology 16: 311-316, 2005.

37. Berg E, Lie RT, Sivertsen $\AA$ and Haaland $\varnothing A$ : Parental age and the risk of isolated cleft lip: A registry-based study. Ann Epidemiol 25: 942.e1-947.e1, 2015.

38. Green RF, Devine O, Crider KS, Olney RS, Archer N, Olshan AF and Shapira SK; National Birth Defects Prevention Study: Association of paternal age and risk for major congenital anomalies from the National Birth Defects Prevention Study, 1997 to 2004. Ann Epidemiol 20: 241-249, 2010. 
39. Reichenberg A, Gross R, Weiser M, Bresnahan M, Silverman J, Harlap S, Rabinowitz J, Shulman C, Malaspina D, Lubin G, et al: Advancing paternal age and autism. Arch Gen Psychiatry 63: 1026-1032, 2006.

40. Hultman CM, Sandin S, Levine SZ, Lichtenstein P and Reichenberg A: Advancing paternal age and risk of autism: New evidence from a population-based study and a meta-analysis of epidemiological studies. Mol Psychiatry 16: 1203-1212, 2011

41. Frans EM, Sandin S, Reichenberg A, Långström N, Lichtenstein $P$, McGrath JJ and Hultman CM: Risk across generations: A population-based study of advancing grandpaternal and paternal age. JAMA Psychiatry 70: 516-521, 2013.

42. Byrne M, Agerbo E, Ewald H, Eaton WW and Mortensen PB: Parental age and risk of schizophrenia: A case-control study. Arch Gen Psychiatry 60: 673-678, 2003.

43. Sipos A, Rasmussen F, Harrison G, Tynelius P, Lewis G, Leon DA and Gunnell D: Paternal age and schizophrenia: A population based cohort study. BMJ 329: 1070, 2004.

44. Frans EM, Sandin S, Reichenberg A, Lichtenstein P, Långström N and Hultman CM: Advancing paternal age and bipolar disorder. Arch Gen Psychiatry 65: 1034-1040, 2008.

45. Glasson EJ, Bower C, Petterson B, de Klerk N, Chaney G and Hallmayer JF: Perinatal factors and the development of autism: A population study. Arch Gen Psychiatry 61: 618-627, 2004.

46. Idring S, Magnusson C, Lundberg M, Ek M, Rai D, Svensson AC, Dalman C, Karlsson H and Lee BK: Parental age and the risk of autism spectrum disorders: Findings from a Swedish population-based cohort. Int J Epidemiol 43: 107-115, 2014.

47. Puleo CM, Schmeidler J, Reichenberg A, Kolevzon A, Soorya LV, Buxbaum JD and Silverman JM: Advancing paternal age and simplex autism. Autism 16: 367-380, 2012.

48. Sebat J, Lakshmi B, Malhotra D, Troge J, Lese-Martin C, Walsh T, Yamrom B, Yoon S, Krasnitz A, Kendall J, et al: Strong association of de novo copy number mutations with autism. Science 316: 445-449, 2007.

49. Crow JF: The origins, patterns and implications of human spontaneous mutation. Nat Rev Genet 1: 40-47, 2000.

50. Malaspina D: Paternal factors and schizophrenia risk: De novo mutations and imprinting. Schizophr Bull 27: 379-393, 2001.

51. Tarín JJ, Brines J and Cano A: Long-term effects of delayed parenthood. Hum Reprod 13: 2371-2376, 1998.

52. Iossifov I, Ronemus M, Levy D, Wang Z, Hakker I, Rosenbaum J, Yamrom B, Lee YH, Narzisi G, Leotta A, et al: De novo gene disruptions in children on the autistic spectrum. Neuron 74 : 285-299, 2012

53. Neale BM, Kou Y, Liu L, Ma'ayan A, Samocha KE, Sabo A, Lin CF, Stevens C, Wang LS, Makarov V, et al: Patterns and rates of exonic de novo mutations in autism spectrum disorders. Nature 485: 242-245, 2012.
54. O'Roak BJ, Vives L, Girirajan S, Karakoc E, Krumm N, Coe BP, Levy R, Ko A, Lee C, Smith JD, et al: Sporadic autism exomes reveal a highly interconnected protein network of de novo mutations. Nature 485: 246-250, 2012.

55. Sanders SJ, Murtha MT, Gupta AR, Murdoch JD, Raubeson MJ, Willsey AJ, Ercan-Sencicek AG, DiLullo NM, Parikshak NN, Stein JL, et al: De novo mutations revealed by whole-exome sequencing are strongly associated with autism. Nature 485: 237-241, 2012.

56. Brown AS, Schaefer CA, Wyatt RJ, Begg MD, Goetz R, Bresnahan MA, Harkavy-Friedman J, Gorman JM, Malaspina D and Susser ES: Paternal age and risk of schizophrenia in adult offspring. Am J Psychiatry 159: 1528-1533, 2002.

57. Malaspina D, Harlap S, Fennig S, Heiman D, Nahon D, Feldman D and Susser ES: Advancing paternal age and the risk of schizophrenia. Arch Gen Psychiatry 58: 361-367, 2001.

58. Foutz J and Mezuk B: Advanced paternal age and risk of psychotic-like symptoms in adult offspring. Schizophr Res 165: 123-127, 2015.

59. McGrath JJ, Petersen L, Agerbo E, Mors O, Mortensen PB and Pedersen CB: A comprehensive assessment of parental age and psychiatric disorders. JAMA Psychiatry 71: 301-309, 2014.

60. Saha S, Barnett AG, Foldi C, Burne TH, Eyles DW, Buka SL and McGrath JJ: Advanced paternal age is associated with impaired neurocognitive outcomes during infancy and childhood. PLoS Med 6: e40, 2009.

61. Wechsler D: Manual for the Wechsler Intelligence Scale for Children. New York: The Psychological Corporation, 1949.

62. Saha S, Barnett AG, Buka SL and McGrath JJ: Maternal age and paternal age are associated with distinct childhood behavioural outcomes in a general population birth cohort. Schizophr Res 115: 130-135, 2009.

63. D'Onofrio BM, Rickert ME, Frans E, Kuja-Halkola R, Almqvist C, Sjölander A, Larsson H and Lichtenstein P: Paternal age at childbearing and offspring psychiatric and academic morbidity. JAMA Psychiatry 71: 432-438, 2014.

64. Janecka M, Haworth CMA, Ronald A, Krapohl E, Happé F, Mill J, Schalkwyk LC, Fernandes C, Reichenberg A and Rijsdijk F: Paternal age alters social development in offspring. J Am Acad Child Adolesc Psychiatry 56: 383-390, 2017.

65. Malaspina D, Reichenberg A, Weiser M, Fennig S, Davidson M, Harlap S, Wolitzky R, Rabinowitz J, Susser E and Knobler HY: Paternal age and intelligence: Implications for age-related genomic changes in male germ cells. Psychiatr Genet 15: 117-125, 2005.

66. Buizer-Voskamp JE, Laan W, Staal WG, Hennekam EA, Aukes MF, Termorshuizen F, Kahn RS, Boks MP and Ophoff RA: Paternal age and psychiatric disorders: Findings from a Dutch population registry. Schizophr Res 129: 128-132, 2011. 